\title{
Paenibacillus cineris sp. nov. and Paenibacillus cookii sp. nov., from Antarctic volcanic soils and a gelatin-processing plant
}

\author{
Correspondence \\ Niall A. Logan \\ n.a.logan@gcal.ac.uk
}

\author{
Niall A. Logan, ${ }^{1}$ Elke De Clerck, ${ }^{2}$ Liesbeth Lebbe, ${ }^{2}$ An Verhelst, ${ }^{2}$ \\ Johan Goris, ${ }^{2}$ Gillian Forsyth, ${ }^{1}$ Marina Rodríguez-Díaz, ${ }^{1}$ Marc Heyndrickx ${ }^{2} \dagger$ \\ and Paul De Vos ${ }^{2}$
}
${ }^{1}$ School of Biological and Biomedical Sciences, Glasgow Caledonian University, Cowcaddens Road, Glasgow G4 OBA, UK
${ }^{2}$ Vakgroep BFM WE10V, Laboratorium voor Microbiologie, Universiteit Gent, K. L. Ledeganckstraat 35, B-9000 Gent, Belgium

\begin{abstract}
Seven strains of aerobic, endospore-forming bacteria were found in soil taken from an active fumarole on Lucifer Hill, Candlemas Island, South Sandwich archipelago, Antarctica, and four strains were from soil of an inactive fumarole at the foot of the hill. Amplified rDNA restriction analysis, 16S rDNA sequence comparisons, SDS-PAGE and routine phenotypic tests support the proposal of two novel species of Paenibacillus, Paenibacillus cineris sp. nov. and Paenibacillus cookii sp. nov., the type strains of which are LMG $18439^{\top}\left(=\mathrm{CIP} 108109^{\top}\right)$ and LMG $18419^{\top}$ $\left(=\right.$ CIP $\left.108110^{\top}\right)$, respectively. A further strain, isolated from a gelatin-production process, showed more than $99 \% 16 \mathrm{~S}$ rDNA sequence similarity to the proposed $P$. cookii type strain and, although the gelatin isolate was atypical when compared with the fumarole isolates by repeated element primed-PCR, SDS-PAGE and phenotypic analyses, it was shown by DNA-DNA reassociation studies to belong to the same species. Strains of $P$. cookii produce spreading growth with motile microcolonies. Both species produce swollen sporangia that are typical for the genus, they both show 97.6 \% 16S rDNA sequence similarity to Paenibacillus azoreducens, they have $51 \cdot 5-51 \cdot 6 \mathrm{~mol} \% \mathrm{G}+\mathrm{C}$ in their DNA and their major fatty acid is anteiso- $\mathrm{C}_{15: 0}$; however, fatty acids $C_{16: 0}$ and anteiso- $C_{17: 0}$ represent, respectively, 18 and $10 \%$ of the total in $P$. cineris, but 11 and $20 \%$ in $P$. cookii.
\end{abstract}

Logan et al. (2000) reported the isolation of aerobic, endospore-forming bacteria from volcanic soils of Candlemas Island in the South Sandwich archipelago in Antarctica and found that two of their strains (LMG 18419 and LMG 18437) found in warm soil taken from a mossy area on an active fumarole at the summit of Lucifer Hill on

Published online ahead of print on 16 January 2004 as DOI 10.1099/ ijs.0.02967-0.

tPresent address: Government Dairy Research Station, Brusselsesteenweg 370, B-9090 Melle, Belgium.

Abbreviations: ARDRA, amplified rDNA restriction analysis; FAMEs, fatty acid methyl esters.

The GenBank/EMBL/DDBJ accession numbers for the 16S rRNA gene sequences of $P$. cineris strains LMG $18439^{\top}(=$ CIP 108109 $)$ and LMG 21976 and $P$. cookii strains LMG $18419^{\top}\left(=\mathrm{CIP} 108110^{\top}\right.$ ), 18437 and R-11600 determined in this work are AJ575658, AJ575659, AJ250317, AJ250319 and AJ438302, respectively.

A photomicrograph of colonies, an extended phylogenetic tree and detailed fatty acid compositions are available as supplementary material in IJSEM Online.
Candlemas Island and one strain (LMG 18439) isolated from the soil of a cold, inactive fumarole at the foot of the hill represented two unidentifiable species of Paenibacillus. The present paper describes the characterization of seven further Paenibacillus strains isolated from the same soils and one isolate from a Belgian gelatin-production plant and proposes the novel species Paenibacillus cineris sp. nov. and Paenibacillus cookii sp. nov., with LMG $18439^{\mathrm{T}}$ and LMG $18419^{\mathrm{T}}$ as the respective type strains. Two other strains not identified by Logan et al. (2000), LMG $18422^{\mathrm{T}}$ and LMG $18435^{\mathrm{T}}$, have since been proposed as the type strains of Bacillus luciferensis (Logan et al., 2002) and Bacillus shackletonii (Logan et al., 2004), respectively.

Antarctic strains were isolated and maintained on trypticase soy agar (TSA; Oxoid) containing $5 \mathrm{mg} \mathrm{MnSO}_{4} \mathrm{l}^{-1}$ (TSA $\mathrm{MnSO}_{4}$ ) to enhance sporulation, as described by Logan et al. (2000). Strains LMG $18419^{\mathrm{T}}$ and LMG 18437 and the additional strains R-11662 (=B1719), R-11663 (=B1735), R-11664 (=B1749), R-11665 $(=\mathrm{B} 1750)$ and R-11666 $(=\mathrm{B} 1751)$ were isolated from a sample of soil by moss on 
a warm, active fumarole (temperature range $30-60{ }^{\circ} \mathrm{C}$; altitude $232 \mathrm{~m}$; site 2 in Logan et al., 2000; Plate I in Tomblin, 1979) near the northern crater of Lucifer Hill, at the top of the scoria cone. Strain LMG $18439^{\mathrm{T}}$ and the further strains LMG 21976 (=B1770), R-11672 (=B1769) and R-11674 ( = B1771) were isolated from a sample of ashy soil near limited moss growth on a cold, inactive fumarole (temperature range $0-15^{\circ} \mathrm{C}$; altitude $20 \mathrm{~m}$; site 4 in Logan et al., 2000) at the southern end of Clinker Gulch (Plate IVb in Tomblin, 1979; Fig. 2 in Longton \& Holdgate, 1979), a gully that appears to represent a former shoreline and which lies at the northern foot of Lucifer Hill. A description of Candlemas Island is given by Logan et al. (2002). Strain R11600 (=B2765), isolated from a gelatin extract of bovine bones (De Clerck \& De Vos, 2002), was included in the study because of its high similarity in $16 \mathrm{~S}$ rDNA sequence to LMG $18419^{\mathrm{T}}$, the type strain of $P$. cookii. This gelatin strain was isolated on a medium the composition of which was based on the gelatin extract that was collected at the point of sampling. The gelatin extract was sterilized and used as a liquid medium for enrichment and isolates were then obtained in pure culture by streak dilution from the enrichment medium onto plates prepared by adding $2 \%$ agar (LAB M) to fresh enrichment medium. Strains were characterized by amplified rDNA restriction analysis (ARDRA), SDS-PAGE analysis, gas chromatographic analysis of fatty acid methyl esters (FAMEs) and phenotypic tests, with numerical analysis of data, as described by Logan $e t$ al. (2000, 2002). For observations on sporangia, cells were grown on TSA $\mathrm{MnSO}_{4}$ and on Bacillus fumarioli agar (BFA) at pH 6.5 (Logan et al., 2000). Antibiotic sensitivities were measured using Mastrings (MAST Diagnostics) on IsoSensitest agar (Oxoid). 16S rDNA sequences were obtained for strains LMG $18419^{\mathrm{T}}$, LMG 18437, LMG $18439^{\mathrm{T}}$, LMG 21976 and R-11600 and aligned with sequences in the EMBL database; cluster analysis was performed using CLUSTAL W (Thompson et al., 1994) and trees were constructed using TREECON software (Van de Peer \& De Wachter, 1994). DNA base compositions of these strains were also determined, as described by Logan et al. (2000).

The strains were found to be Gram-variable or Gramnegative, facultatively anaerobic, motile rods that formed ellipsoidal spores that lay paracentrally or subterminally in swollen or slightly swollen sporangia (Fig. 1). On TSA plates, the strains from site 4 (proposed as P. cineris) formed discrete colonies, while those from site 2 (proposed as $P$. cookii) showed yellowish, spreading growth with motile colonies (Supplementary Fig. A in IJSEM Online), which was reminiscent of some strains that were previously named Bacillus circulans (illustrated in Logan \& Turnbull, 2003), but which are now allocated to Paenibacillus glucanolyticus, Paenibacillus lautus and some unidentified Paenibacillus spp. (Alexander \& Priest, 1989; N. A. Logan, unpublished observations), and also reminiscent of colonies of Paenibacillus alvei (illustrated in Logan \& Turnbull, 2003), but they did not have the odour associated with cultures of $P$. alvei. As well as showing different colonial morphologies,
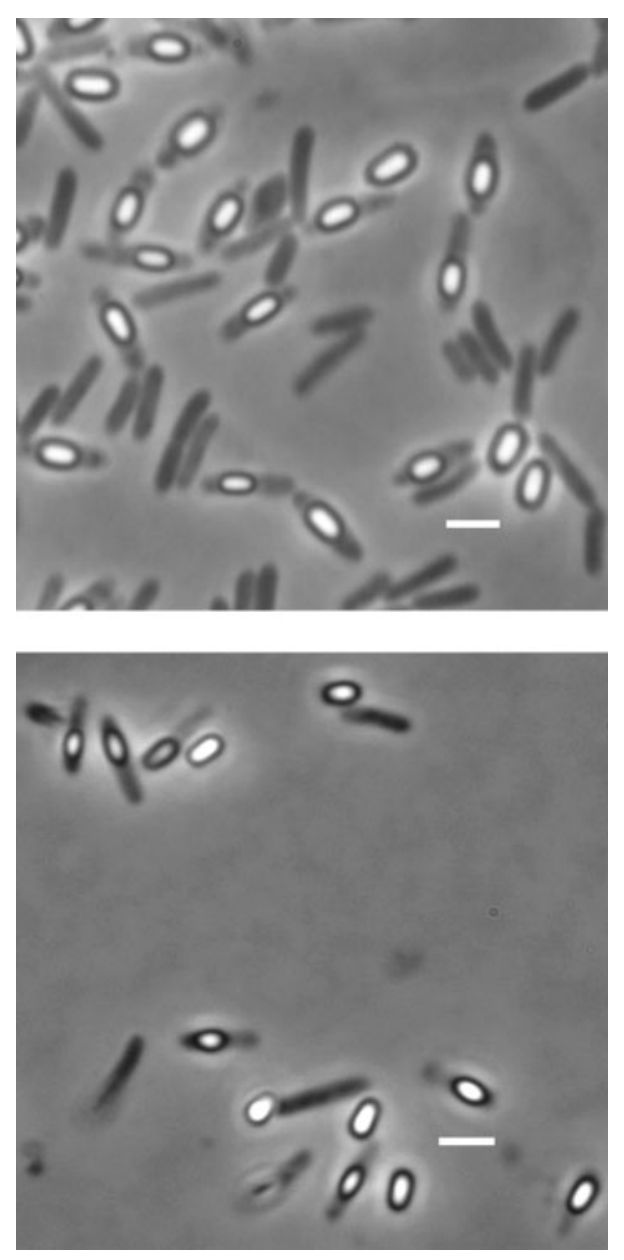

Fig. 1. Phase-contrast photomicrographs of sporangia and vegetative cells of the type strains of Paenibacillus cineris sp. nov. (top), showing ellipsoidal endospores that are located paracentrally and subterminally and swell the sporangia, and Paenibacillus cookii sp. nov. (bottom), showing ellipsoidal endospores that lie subterminally and swell the sporangia slightly. Bars, $2 \mu \mathrm{m}$.

the two groups of strains from the separate Candlemas Island sites showed two distinct patterns of results in the phenotypic characters; however, each group of strains showed sufficient within-group phenotypic variation to suggest that they are not repeated isolations of the same strain. The seven strains from site 2 clustered together at $92.5 \%$ similarity in a UPGMA cluster analysis (not shown) based upon these characters; the gelatin isolate joined them at $85 \%$ similarity, and this cluster merged with strains of Paenibacillus polymyxa and other Paenibacillus species at $80 \%$ similarity. In the same analysis, the four strains from site 4 clustered together at $90 \%$ similarity and this cluster merged with other strains of Paenibacillus and strains from site 2 at only $77 \cdot 5 \%$ similarity. These results indicate that the two groups are phenotypically distinct from each other and from established species of Paenibacillus. 
It is of interest that, although the temperature of the soil of the active fumarole at site 2 ranged from $30^{\circ} \mathrm{C}$ and that of the dead fumarole at site 4 ranged from $5^{\circ} \mathrm{C}$, all of our isolates showed similar temperature ranges for growth, with minima at $0{ }^{\circ} \mathrm{C}$ and maxima at $50{ }^{\circ} \mathrm{C}$. Perhaps these temperature ranges reflect a versatility necessary to organisms living in such volcanic soils where geothermal activity at a given site is impermanent, as the organisms do not appear to have evolved growth ranges restricted to the measured temperatures of their soils at the times of sampling. The $\mathrm{pH}$ ranges of the strains were also broadly similar, but showed appreciable variation within the groups, with the strains from site 2 showing minima of $5 \cdot 0-5 \cdot 5$ and maxima of $7 \cdot 0-10 \cdot 0$ and those from site 4 having minima of $5 \cdot 0-6 \cdot 5$ and maxima of $7 \cdot 5-11 \cdot 0$.

The two groups of strains could also be distinguished by their fatty acid profiles; although anteiso- $\mathrm{C}_{15: 0}$ was the dominant component in all of the strains, as it was for the other Paenibacillus strains studied (Table 1), the strains from site 4 had more of this fatty acid and more of $\mathrm{C}_{16: 0}$ than did the strains from site 2, while the strains from site 2 had more of anteiso- $\mathrm{C}_{17: 0}$ than did strains from site 4 .

Comparison of the ARDRA patterns of strains LMG $18419^{\mathrm{T}}$ and LMG 18437 with a database of over 1000 authentic strains of species of aerobic, endospore-forming bacteria did not yield an identification; the highest similarity found for LMG $18419^{\mathrm{T}}$ and 18437 was $77 \%$ with strains of Paenibacillus amylolyticus and Paenibacillus glucanolyticus. The highest similarity found for LMG $18439^{\mathrm{T}}$ was $73 \%$ with LMG $18419^{\mathrm{T}}$ and LMG 18437 and strains of P. amylolyticus and $P$. glucanolyticus. The results of SDS-PAGE analysis showed a close grouping within isolates from each site (Fig. 2). The gelatin isolate R-11600 clustered with the isolates from site 2 but showed a somewhat different profile. In $16 \mathrm{~S}$ rDNA sequence comparisons with entries in the EMBL database, the closest matches achieved for LMG $18419^{\mathrm{T}}$ and LMG 18437 (EMBL accession nos AJ250317 and AJ250319) were $97 \cdot 6 \%$ to Paenibacillus azoreducens (Fig. 3); the closest matches achieved for LMG $18439^{\mathrm{T}}$ and LMG 21976 (EMBL accession nos AJ575658 and AJ575659) were also $97.6 \%$ to $P$. azoreducens (Fig. 3). The gelatin isolate R-11600 (AJ438302) showed $99 \cdot 7 \%$ similarity to $P$. cookii LMG $18419^{\mathrm{T}}$. A fuller $16 \mathrm{~S}$ rDNA sequence comparison tree is available as Supplementary Fig. B in IJSEM Online.

The six other strains from site 2 were further compared with the gelatin isolate by means of rep-PCR with the (GTG) $)_{5}$ and BOX A1R primers (Fig. 4). As with PAGE, this technique also showed the gelatin isolate to be an outlier of the cluster containing the fumarole isolates from site 2 . The gelatin isolate also produced spreading, motile colonies on agar media and differed from the Candlemas isolates of P. cookii in only two phenotypic characters: it produced acid from adonitol and it did not produce acid from D-fructose. A DNA-DNA reassociation of $78 \%$ was found between
Table 1. Some characters for distinguishing between $P$. cineris and P. cookii and closely related Paenibacillus species

Taxa: 1, P. cineris sp. nov.; 2, P. cookii sp. nov.; 3, P. azoreducens; 4, P. amylolyticus; 5, P. polymyxa; 6, P. glucanolyticus; 7, P. borealis.,$+ \quad>85 \%$ positive; $(+), 75-84 \%$ positive; $V$, variable (26-74\% positive); (-), $16-25 \%$ positive;,$- 0-15 \%$ positive; $\mathrm{w}$, weak positive reaction; $+/ \mathrm{W}$, positive or weak positive reaction; $\mathrm{v}(\mathrm{w})$, variable and, when positive, the reaction is weak. Fatty acid data for P. azoreducens are from Meehan et al. (2001) and those for P. borealis are from Elo et al. (2001). With the exception of microscopic observations, growth at $50^{\circ} \mathrm{C}$ and casein hydrolysis, all characters were determined using tests in API $20 \mathrm{E}$ and 50 CHB systems. All species produce ellipsoidal spores that swell the sporangia.

\begin{tabular}{|c|c|c|c|c|c|c|c|}
\hline Character & 1 & 2 & 3 & 4 & 5 & 6 & 7 \\
\hline Spore position ${ }^{\star}$ & CS & S & S & ST & S & $\mathrm{T}$ & ST \\
\hline Spreading growth & - & + & - & - & - & $\mathrm{V}$ & - \\
\hline Growth at $50^{\circ} \mathrm{C}$ & + & + & + & - & - & - & - \\
\hline Gelatin hydrolysis & - & $\mathrm{V}$ & $\mathrm{w}$ & + & + & + & - \\
\hline Casein hydrolysis & $\mathrm{W}$ & $\mathrm{W}$ & - & $\mathrm{W}$ & + & + & - \\
\hline Production of $\mathrm{H}_{2} \mathrm{~S}$ & - & - & + & - & - & - & + \\
\hline Voges-Proskauer & $\mathrm{v}(\mathrm{w})$ & + & $\mathrm{W}$ & - & $\mathrm{V}$ & - & - \\
\hline Gas production from glucose & $e-$ & - & - & - & - & + & $-\dagger$ \\
\hline \multicolumn{8}{|l|}{ Acid from: } \\
\hline$N$-Acetylglucosamine & + & $(-)$ & + & + & - & + & + \\
\hline D-Arabinose & $\mathrm{v}(\mathrm{w})$ & - & + & - & - & - & + \\
\hline L-Fucose & - & $+/ \mathrm{w}$ & - & - & - & $\mathrm{V}$ & $\mathrm{W}$ \\
\hline Glycerol & - & $\mathrm{w}$ & $\mathrm{w}$ & - & + & + & $-\dagger$ \\
\hline Glycogen & $\mathrm{V}$ & + & + & + & + & + & + \\
\hline meso-Inositol & + & - & - & - & - & - & - \\
\hline 5-Keto-D-gluconate & - & $\mathrm{v}(\mathrm{W})$ & - & $\mathrm{W}$ & - & - & $\mathrm{W}$ \\
\hline Mannitol & + & - & + & + & + & + & + \\
\hline D-Melezitose & + & + & - & - & V & + & + \\
\hline Sorbitol & $\mathrm{v}(\mathrm{w})$ & - & - & - & - & - & + \\
\hline Oxidase & + & + & - & - & - & + & - \\
\hline Growth in $5 \% \mathrm{NaCl}$ & - & + & - & - & - & + & - \\
\hline \multicolumn{8}{|l|}{ Fatty acid content: $\ddagger$} \\
\hline iso- $\mathrm{C}_{15: 0}$ & 6 & $6 \cdot 5$ & 6 & 6 & $10 \cdot 5$ & 7 & $12 \cdot 5$ \\
\hline anteiso- $\mathrm{C}_{15: 0}$ & 46 & 36 & 40 & $42 \cdot 5$ & 52 & $58 \cdot 5$ & 43 \\
\hline $\mathrm{C}_{16: 0}$ & 18 & 11 & 22 & 20 & 12 & 7 & 12 \\
\hline iso- $\mathrm{C}_{16: 0}$ & 9 & 13 & $8 \cdot 5$ & $10 \cdot 5$ & 7 & 5 & $10 \cdot 5$ \\
\hline anteiso- $\mathrm{C}_{17: 0}$ & 10 & 20 & 20 & $8 \cdot 5$ & $4 \cdot 5$ & $5 \cdot 5$ & $2 \cdot 5$ \\
\hline
\end{tabular}

${ }^{*} \mathrm{C}$, Central/paracentral; s, subterminal; $\mathrm{T}$, terminal.

†Our results for the type strain differ from those given in the published description (Elo et al., 2001).

¥Major components are expressed as percentages of the total and rounded to nearest $0.5 \%$.

R-11600 and LMG $18419^{\mathrm{T}}$, demonstrating that these strains belong to the same species.

It may seem remarkable that $P$. cookii has been isolated from two such disparate and geographically separated environments, but Logan et al. (2000) found Bacillus fumarioli in 


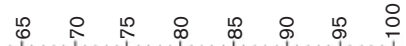

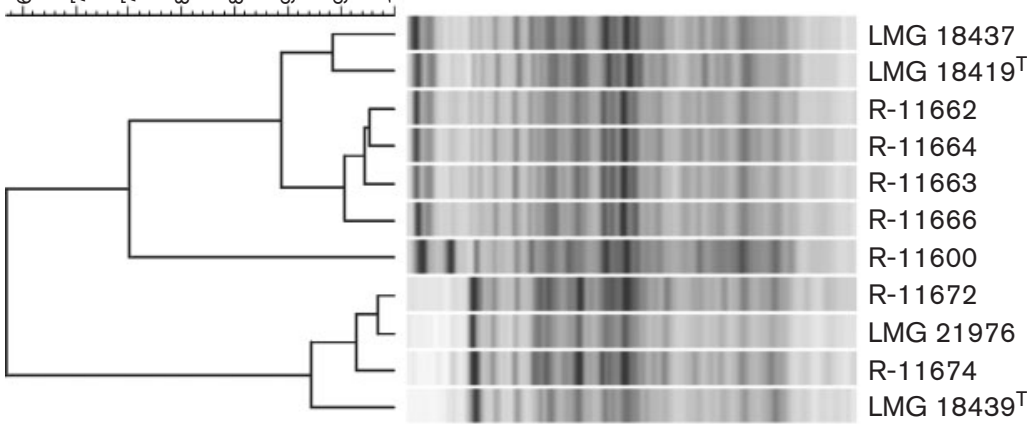

Fig. 2. Normalized computer profiles from SDS-PAGE analyses of whole-cell proteins of $P$. cineris and $P$. cookii strains. The dendrogram is based on UPGMA clustering of the correlation coefficient $(r)$ of the total protein profiles.

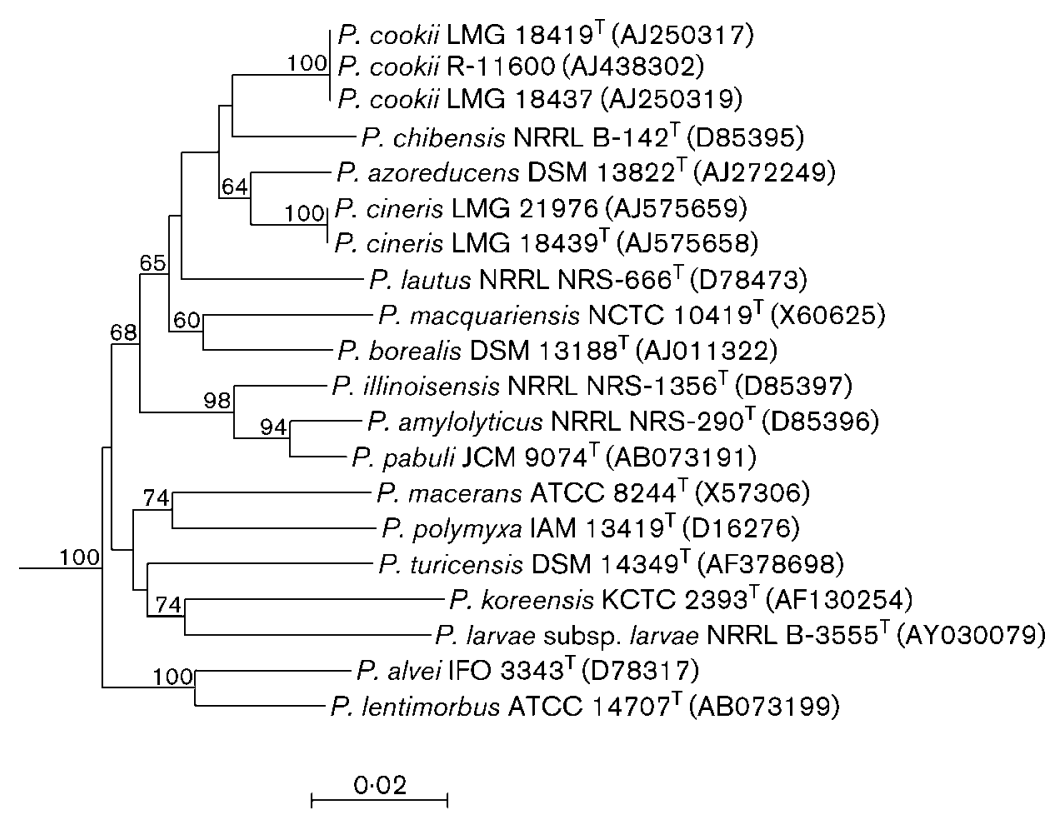

Fig. 3. Phylogenetic positions of $P$. cineris and $P$. cookii among the type strains of a selection of other Paenibacillus species, based on neighbour-joining clustering of a $1367 \mathrm{bp}$ portion of the 16S rRNA gene. Bootstrap values (expressed as percentages of 1000 replications) $\geqslant 60 \%$ are shown at branch points. Accession numbers are given in parentheses. The scale bar indicates 0.02 nucleotide substitutions per nucleotide position. Tree rooted using B. subtilis DSM $10^{\top}$ (AJ276351) as an outgroup.

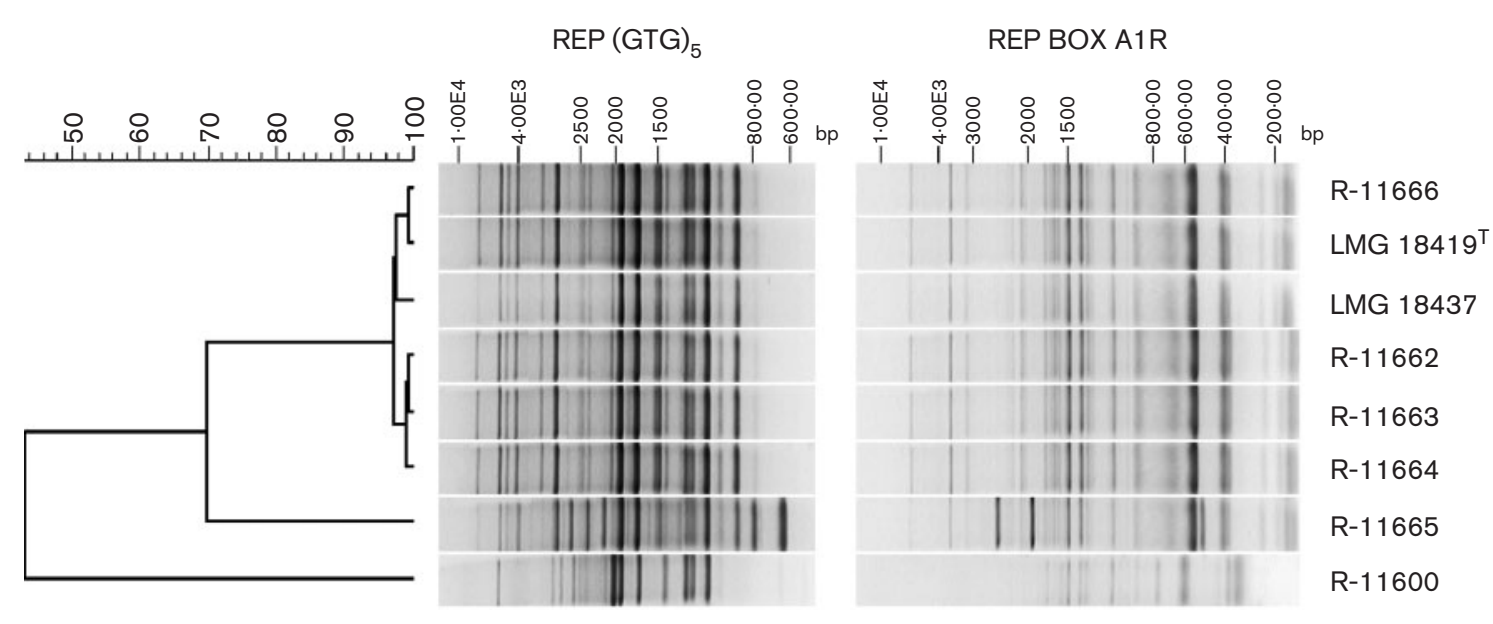

Fig. 4. Cluster analysis based on linearly combined $B O X-$ and $(G T G)_{5}-P C R$ profiles of $P$. cookii isolates. The dendrogram was constructed using UPGMA with correlation levels expressed as percentages of Pearson's correlation coefficient. 
both northern Victoria Land and Candlemas Island, which are geographically isolated from each other, presumably distributed by the action of wind, and this species has subsequently been isolated from European and American gelatin-production plants. Our failure to identify the Candlemas Island strains and the gelatin isolate by the genotypic and phenotypic methods applied, the similarities of the Antarctic strains to each other in the phenotypic analyses and the DNA relatedness of the gelatin isolate to one of the groups of Antarctic strains support the proposal of two novel species, the descriptions of which follow.

\section{Description of Paenibacillus cineris sp. nov.}

Paenibacillus cineris (ci'ne.ris. L. gen. masc. n. cineris of/ from ash, referring to the volcanic, ash-based soil from which the type strain was isolated).

Cells are motile, round-ended rods $(0 \cdot 7-0 \cdot 9 \times 2 \cdot 5-4 \cdot 0 \mu \mathrm{m})$ occurring singly and in pairs. Gram-negative or Gramvariable. Endospores are formed within 2-3 days incubation on BFA at $30^{\circ} \mathrm{C}$; they are ellipsoidal, lie paracentrally and subterminally and swell the sporangia (Fig. 1, top). After 2 days at $30^{\circ} \mathrm{C}$, colonies are $1-5 \mathrm{~mm}$ in diameter, low convex and circular with slightly irregular edges; they are opaque and glossy and light beige to greyish in colour with paler margins. Grows on nutrient agar. Facultatively anaerobic, catalase- and oxidase-positive. Minimum temperature for growth lies between 8 and $15^{\circ} \mathrm{C}$ and the maximum growth temperature is $50{ }^{\circ} \mathrm{C}$. Minimum $\mathrm{pH}$ for growth lies between $5 \cdot 0$ and $6 \cdot 5$, the optimum $\mathrm{pH}$ for growth is $7 \cdot 0$ and the maximum $\mathrm{pH}$ for growth varies between strains and lies between $7 \cdot 5$ and $11 \cdot 0$. Growth occurs in the presence of $3 \% \mathrm{NaCl}$, but is inhibited by $5 \% \mathrm{NaCl}$. Hydrolysis of casein is weakly positive. In the API 20E strip, reactions for ONPG hydrolysis and nitrate reduction are positive. Voges-Proskauer reaction is variable and positive reactions are weak. Gelatin is not hydrolysed and reactions for arginine dihydrolase, lysine decarboxylase, ornithine decarboxylase, citrate utilization, hydrogen sulphide production, urease, tryptophan deaminase and indole production are negative. Hydrolysis of aesculin is positive. Acid is produced without gas from the following carbohydrates in the API $50 \mathrm{CH}$ gallery using the $\mathrm{CHB}$ suspension medium: $\mathrm{N}$-acetylglucosamine, amygdalin, L-arabinose, arbutin, D-cellobiose, D-fructose, galactose, gentiobiose, D-glucose, meso-inositol, lactose, maltose, mannitol, D-melezitose, D-melibiose, methyl D-glucoside, methyl D-mannoside (weak), methyl xyloside, D-raffinose, ribose, salicin, starch, sucrose, D-trehalose, D-turanose and $\mathrm{D}$-xylose. Production of acid is variable for D-arabinose (positives are weak), glycogen, inulin, D-mannose and sorbitol (positives are weak). Acid is not produced from the following carbohydrates: adonitol, D- and L-arabitol, dulcitol, erythritol, D- and L-fucose, glycerol, gluconate, 2-keto-D-gluconate, 5-keto-D-gluconate, D-lyxose, rhamnose, L-sorbose, D-tagatose, L-xylose and xylitol. Strains are resistant to disks of the antibiotics kanamycin $(30 \mu \mathrm{g})$ and streptomycin $(25 \mu \mathrm{g})$ and moderately resistant to tetracycline $(100 \mu \mathrm{g})$; sensitive to ampicillin $(25 \mu \mathrm{g})$, chloramphenicol $(50 \mu \mathrm{g})$, colistin sulphate $(100 \mu \mathrm{g})$, nalidixic acid $(30 \mu \mathrm{g})$ and nitrofurantoin $(50 \mu \mathrm{g})$. The major cellular fatty acids are anteiso- $\mathrm{C}_{15: 0}, \mathrm{C}_{16: 0}$, anteiso$\mathrm{C}_{17: 0}$ and iso- $\mathrm{C}_{16: 0}$ (respectively representing about 46 , 18,10 and $9 \%$ of total fatty acids). The following fatty acids are present in smaller, decreasing amounts (between about 6 and $1 \%$ ): iso- $\mathrm{C}_{15: 0}, \mathrm{C}_{14: 0}$, iso- $\mathrm{C}_{17: 0}, \mathrm{C}_{15: 0}$ and iso$\mathrm{C}_{14: 0}$. (Supplementary Table in IJSEM Online).

The $\mathrm{G}+\mathrm{C}$ content is $51.5 \mathrm{~mol} \%$ for the type strain, strain LMG $18439^{\mathrm{T}} \quad\left(=\mathrm{CIP} \quad 108109^{\mathrm{T}}=\right.$ Logan collection no. $\mathrm{B} 1768^{\mathrm{T}}=$ isolate SSI068); the $16 \mathrm{~S}$ rDNA sequence of this strain is deposited at EMBL under accession number AJ575658. In the variable reactions listed above, the type strain grows in the temperature range $15-50{ }^{\circ} \mathrm{C}$ and in the $\mathrm{pH}$ range $5 \cdot 0-10 \cdot 5$; it is negative for the Voges-Proskauer reaction, production of acid is weak for $\mathrm{D}$-arabinose, inulin and sorbitol and negative for glycogen and D-mannose. Reference strains are LMG 21976, R-11672 and R-11674. Strains were isolated from the ashy soil of a cold, dead fumarole at the foot of Lucifer Hill, a volcano on Candlemas Island, South Sandwich archipelago, Antarctica.

\section{Description of Paenibacillus cookii sp. nov.}

Paenibacillus cookii [cook'i.i. N.L. gen. n. cookii of Cook, referring to Captain James Cook, of HMS Resolution, who discovered Candlemas Island on Candlemas Day (2 February), 1775].

Cells are motile, round-ended rods $(0 \cdot 6-0 \cdot 8 \times 3 \cdot 0-3 \cdot 5 \mu \mathrm{m})$ occurring singly and in pairs. Gram-negative or Gramvariable. Endospores are formed within 2-3 days incubation on BFA incubated at $30^{\circ} \mathrm{C}$; they are ellipsoidal, lie subterminally and swell the sporangia slightly (Fig. 1, bottom). After 2 days at $30^{\circ} \mathrm{C}$, colonies are $1-4 \mathrm{~mm}$ in diameter, convex, yellowish and transparent with opaque centres; motile microcolonies are formed and spread across the surface of the agar, rotating clockwise and anticlockwise (Supplementary Fig. A). Grows on nutrient agar. Facultatively anaerobic. Catalase-positive or weakly positive and oxidase-positive. Minimum temperature for growth lies between 15 and $20^{\circ} \mathrm{C}$ and the maximum growth temperature is $50^{\circ} \mathrm{C}$. Minimum pH for growth lies between 5 and $5 \cdot 5$, the optimum $\mathrm{pH}$ for growth is $7 \cdot 0$ and the maximum $\mathrm{pH}$ for growth lies between $7 \cdot 5$ and 10 . Growth occurs in the presence of $5 \% \mathrm{NaCl}$, but is inhibited by $7 \% \mathrm{NaCl}$. Casein hydrolysis is positive but weak. In the API 20E strip, ONPG hydrolysis, Voges-Proskauer reaction and nitrate reduction are positive. Hydrolysis of gelatin is variable while reactions for arginine dihydrolase, lysine decarboxylase, ornithine decarboxylase, citrate utilization, hydrogen sulphide production, urease, tryptophan deaminase and indole production are negative. In the API $50 \mathrm{CH}$ gallery using the $\mathrm{CHB}$ suspension medium, hydrolysis of aesculin is positive and acid is produced without gas from the following carbohydrates: amygdalin, L-arabinose, arbutin, D-cellobiose, galactose, gentiobiose, D-glucose, glycerol, glycogen, lactose, 
maltose, D-melezitose, D-melibiose, methyl D-glucoside, methyl xyloside, D-raffinose, ribose, salicin, starch, sucrose, D-trehalose, D-turanose, D-xylose. Production of acid without gas is variable for the following carbohydrates: $N$ acetylglucosamine, D-fructose (weak), L-fucose, gluconate (weak), 5-keto-D-gluconate (weak), D-mannose and methyl D-mannoside. Acid is not produced from the following carbohydrates: adonitol, D-arabinose, D- and L-arabitol, dulcitol, erythritol, D-fucose, meso-inositol, inulin, 2-ketoD-gluconate, D-lyxose, mannitol, rhamnose, sorbitol, Lsorbose, D-tagatose, L-xylose and xylitol. Sensitive to disks of the antibiotics ampicillin $(25 \mu \mathrm{g})$, chloramphenicol $(50 \mu \mathrm{g})$, colistin sulphate $(100 \mu \mathrm{g})$, kanamycin $(30 \mu \mathrm{g})$, nalidixic acid $(30 \mu \mathrm{g})$, nitrofurantoin $(50 \mu \mathrm{g})$, streptomycin $(25 \mu \mathrm{g})$ and tetracycline $(100 \mu \mathrm{g})$. The major cellular fatty acids are anteiso- $\mathrm{C}_{15: 0}$, anteiso- $\mathrm{C}_{17: 0}$, iso- $\mathrm{C}_{16: 0}, \mathrm{C}_{16: 0}$ and iso- $\mathrm{C}_{15: 0}$ (respectively representing about $36,20,13,11$ and $6.5 \%$ of total fatty acids). The following fatty acids are present in smaller, decreasing amounts (between about 5 and $1 \%$ ): iso- $\mathrm{C}_{17: 0}, \mathrm{C}_{14: 0}$, iso- $\mathrm{C}_{14: 0}, \mathrm{C}_{12: 0}$ and $\mathrm{C}_{15: 0}$ (Supplementary Table).

The $\mathrm{G}+\mathrm{C}$ content is $51 \cdot 6 \mathrm{~mol} \%$ for the type strain, strain LMG $18419^{\mathrm{T}} \quad\left(=\mathrm{CIP} \quad 108110^{\mathrm{T}}=\right.$ Logan collection no. $\mathrm{B} 1718^{\mathrm{T}}=$ isolate SSI018); the $16 \mathrm{~S}$ rDNA sequence of this strain is deposited at EMBL under accession number AJ250317. In the variable reactions listed above, the type strain has a minimum growth temperature of $20{ }^{\circ} \mathrm{C}$ and grows in the $\mathrm{pH}$ range 5.0-9.5; it does not hydrolyse gelatin; acid production is positive for L-fucose, weak for gluconate and D-mannose and negative for $\mathrm{N}$-acetylglucosamine, D-fructose, 5-keto-D-gluconate and methyl Dmannoside. Reference strains are LMG 18437, R-11600, R-11662, R-11664, R-11665 and R-11666. Isolated from geothermal soil taken from an active fumarole on Lucifer Hill, a volcano on Candlemas Island, South Sandwich archipelago, Antarctica, and from a gelatin extract of bovine bones (strain R-11600).

\section{Acknowledgements}

We are very grateful to P. Convey of the British Antarctic Survey for collecting soil samples from Candlemas Island and to H. G. Trüper for advice on nomenclatural etymology. We are most grateful to bioMérieux sa and bioMérieux Inc. for providing API materials and for supporting G.F. and M.R.-D.; P.D.V. and M.H. are indebted to the National Fund for Scientific Research (Belgium) for a position as Research Director and Postdoctoral Research Fellow, respectively. For personnel and research grants, P.D.V. thanks the Onderzoeksfonds RUG (nos 01105893 and 011A1096) and the FSR (no. 3G.0072.96).

\section{References}

Alexander, B. \& Priest, F. G. (1989). Bacillus glucanolyticus, a new species that degrades a variety of $\beta$-glucans. Int J Syst Bacteriol 39, 112-115.

De Clerck, E. \& De Vos, P. (2002). Study of the bacterial load in a gelatine production process focussed on Bacillus and related endosporeforming genera. Syst Appl Microbiol 25, 611-617.

Elo, S., Suominen, I., Kämpfer, P., Juhanoja, J., SalkinojaSalonen, M. \& Haahtela, K. (2001). Paenibacillus borealis sp. nov., a nitrogen-fixing species isolated from spruce forest humus in Finland. Int J Syst Evol Microbiol 51, 535-545.

Logan, N. A. \& Turnbull, P. C. B. (2003). Bacillus and other aerobic endospore-forming bacteria. In Manual of Clinical Microbiology, 8th edn, vol. 1, pp. 445-460. Edited by P. R. Murray, E. J. Baron, J. H. Jorgensen, M. A. Pfaller \& R. H. Yolken. Washington, DC: American Society for Microbiology.

Logan, N. A., Lebbe, L., Hoste, B., Goris, J., Forsyth, G., Heyndrickx, M. \& De Vos, P. (2000). Aerobic endospore-forming bacteria from geothermal environments in northern Victoria Land, Antarctica, and Candlemas Island, South Sandwich archipelago, with the proposal of Bacillus fumarioli sp. nov. Int J Syst Evol Microbiol 50, 1741-1753.

Logan, N. A., Lebbe, L., Verhelst, A., Goris, J., Forsyth, G., Rodríguez-Díaz, M., Heyndrickx, M. \& De Vos, P. (2002). Bacillus luciferensis sp. nov., from volcanic soil on Candlemas Island, South Sandwich archipelago. Int J Syst Evol Microbiol 52, 1985-1989.

Logan, N. A., Lebbe, L., Verhelst, A., Goris, J., Forsyth, G., Rodríguez-Díaz, M., Heyndrickx, M. \& De Vos, P. (2004). Bacillus shackletonii sp. nov., from volcanic soil on Candlemas Island, South Sandwich archipelago. Int J Syst Evol Microbiol 54, 373-378.

Longton, R. E. \& Holdgate, M. W. (1979). The South Sandwich Islands. IV. Botany. Br Antarct Surv Sci Rep 94, 1-51.

Meehan, C., Bjourson, A. J. \& McMullan, G. (2001). Paenibacillus azoreducens sp. nov., a synthetic azo dye decolorizing bacterium from industrial wastewater. Int J Syst Evol Microbiol 51, 1681-1685.

Thompson, J. D., Higgins, D. G. \& Gibson, T. J. (1994). CLUSTAL W: improving the sensitivity of progressive multiple sequence alignment through sequence weighting, position-specific gap penalties and weight matrix choice. Nucleic Acids Res 22, 4673-4680.

Tomblin, J. F. (1979). The South Sandwich Islands. II. The geology of Candlemas Island. Br Antarct Surv Sci Rep 92, 1-33.

Van de Peer, Y. \& De Wachter, R. (1994). TREECON for Windows: a software package for the construction and drawing of evolutionary trees for the Microsoft Windows environment. Comput Appl Biosci 10, 569-570. 